\title{
Sciendo
}

DOI: $10.2478 /$ jolace-2019-0016

\section{Faithful Prodigals, Precarious Polity and Re-Jigging National Discourse: Readings from Two African Novels}

\author{
Ogbu Chukwuka Nwachukwu \\ Alex- Ekwueme Federal University, Nigeria \\ chukwukanwachukwu158@gmail.com
}

\begin{abstract}
This study is informed by the observation of some dangerous threats to faith's missionary and human developmental goals as well as Salvationist stance. The alarm has been sounded that fanaticism of any colour at all is not only inimical to the raison detre of faith's cardinal objectives but more tellingly, constitutes a serious endangerment of humanity, particularly the Nigerian enterprise. Deploying exemplifications from Chinua Achebe's Things Fall Apart (1958) and Chimamanda Ngozi Adichie's Purple Hibiscus (2006) in an eclectic combination of a body of qualitative instances drawn from the Islamic and the Christian faiths the paper underscores the danger inherent in bigoted faith both to faith itself and to the society. The paper urges the painstaking reification/ inculcation of the principles of tolerance and patriotism in children in their formative years through literary creativity, the precepts of inter and intra religious tolerance respecting the West African sub-regional stance for secular imperatives and egalitarian. This is to enthrone lasting peace in the African sub continent and the world a piece.

Key words: faithful prodigals, precarious polity, re-jig, national discourse, formative years, religious (in)tolerance, christianity, islam, reification.

\section{Introduction}

This paper captures the intrinsic and extrinsic worth of Faith as well as its negative and positive dimensions in human development with regard to West Africa, particularly Nigeria. Although, Femi Ojo-Ade sees Christianity in Africa only as an instrument of colonialism, a source of political instability and a destroyer of African culture (2001, pp.126 - 7), Ngugi Wa Thiong'o observes that the African "cannot escape from the church and its influence," where Ekollo as cited by 0joAde points to Christianity's central role in African affairs and concludes that "whether we consider it an inhibitory...force or ... an expansive factor, it remains one of the factors that must be taken into consideration in what we call 'the politico-cultural revolution of black Africa'” (pp. 126 - 7).
\end{abstract}




\section{Faith}

The basis for the existence and fructification of the Christian and the Islamic religions is faith. To the Christian, "faith is the assurance of things hoped for, the conviction of things not seen, the substance of hope" (Hebrews, 11:1). These things hoped for include the promises of everlasting life in the hereafter. Faith is also, "a conduct of work inspired by the complete surrender to mental acceptance." This means that faith necessitates work since "faith without work is dead." This particular configuration of faith is the safety verve as well as the driving force for the works of charity and the development of the human society by the Christian faithful such as missionaries, evangelists and educators. It is also, in a sense, the galvanizing element toward certain leanings demonstrated in anarchy, violence and stasis by errant prodigals of faith.

For the Islamic faithful, "faith is at once an affirmation of truth and surrender to the truth so affirmed" (Surat Al- Jathiya, 45:5). This truth in Islam is the belief in the unity of the Tawheed (God), as expressed in the primary Kalimah (word) of Islam, as "Laa ilaaha ilallah," meaning: "There is no one worthy of worship but Allah(God). What necessitates belief in a supreme being is man's sense of inadequacy, of fear of the nebulous and initially his feeling and (later) conviction that some supernatural force is at the centre of control at both the celestial and the terrestrial planes of existence. So, faith has rewards which are the essential drivers of the faithful either to better or to batter and embitter mankind or sections of humanity.

Faith is the evidence that the rewards promised or encapsulated in the creed are real and serve as recompense to the faithful. Thus, aside promises of movement to a safer and surer plane with its attendant trappings of enjoyment and bliss, faith for the Islamist promises "unhindered progress and success in this world and in the hereafter; whereas failure and ignominy are the ultimate lot of those who refuse to believe it" (Quran, 8:32). The Christian basis for salvation and immortality is ingrained in God's grace through man's faith to Him (Ephesians 2:8). The exhortation "all things work together for good to those who love and serve Him faithfully" (Romans, 8:32) clinches the functionality of faith. This is what necessitates the practice of noble deeds which are perquisites for entry into the treasure troves of these promises. However, this functionality also impels the prodigals of faith to enforce their will not respecting the hallowed injunction of peace which their faith commands and commends.

\section{Faith and Human Development}

Faith is at the core of Homo sapiens' movement from crudity to sophistication, from animalistic tendencies to temperance, from ignorance to enlightenment and knowledge. Although, Phillip Sydney posits that poetry is the "first light giver" 
("Apology"), faith is probably the actual first giver of light: "And God said, Let there be light: and there was light" (Genesis, 1:3). The Church has been at the centre of man's advancement. Roland H. Bainton has captured the Church and State symbiosis in the stabilization and advancement of Europe with the rebarbative effect this has on other continents, notably Africa (1954, p. 85). Bainton further notes that "Under the leading of the Church arose the universities for the study of theology which teaches about God and philosophy trying to understand the universe, law and medicine" (p. 100).

Furthermore, Dimgba Igwe asserts that the Japanese Shintoist ethic of hard work and honour promises on pain of death led to the work ethic that placed Japan dangerously close to American capital in the 1990s (2014, pp.32 -33). Of the Chinese, the writer ruminates:

Perhaps, one good thing that came out of Mao Zedong's Cultural (faith) Revolution in China is that despite all the evil unleashed on those who were unfortunate to be the targets, it inspired confidence in the Chinese in the belief in themselves and their products. Nearly fifty years down the line, China is now a globalized economic super power second only to the United States' economy (pp. 33 -34).

On another score, Max Weber in Capitalism and the Protestant Ethic has argued that the success of American capitalism and the consequent de facto superpower status which she now enjoys is a direct result of protestant ethics: a study of the relationship between the ethics of ascetic Protestantism and the emergence of the spirit of modern capitalism $(1967$, p. 3). Churches have also contributed to the success of America by encouraging virtue; and various social science research reports have shown that churches provide direct economic and social benefits to communities (Monrose, 2014, pp.2-4).

But faith helps and hinders. Most wars fought by humanity arose and still arise because of misguided faith. Pope Urban whetted the nobles of Claremont, France, to fight the Mohammedan Turks who had broken into the holy land of Christ's nativity:

An accursed race (Turks) has invaded the lands of the East. Christians are enslaved, tortured, (and) killed. The swordsmen practice on them to see whether a neck can be cut in two with one blow. Churches are used as stables, or wrecked or turned into Mohammedan Mosques. The Church of the Blessed Virgin Mary is in their hands. Who can take vengeance if not you who have won glory in arms? .... Come now to the defense of Christ (Bainton, p. 94). 
So, the defense of Christ or Allah (more appropriately, Mohammad) remains, erroneously, the bane and scourge of faith, the source of prodigality. But then, the Crusades and the early Jihads gave rise to explorations, expeditions, conquests, colonization and domination and exploitation which in turn led at least, marginally, to the civilization of the greater globe with Africa as the biggest victim and marginally, beneficiary. For instance, for Henry the Navigator of Portugal, exploration and expeditions of discovery "formed part of the never ending war between Christianity and Islam (Readers Digest, pp. 573-3). It is this quest to entrench faith that led to the discovery of America by Christopher Columbus an Italian explorer sponsored by the Spanish monarchs, Ferdinand and Isabella ( $\mathrm{p}$. 573).

\section{Faith's Prodigality and the Imperatives of National Cohesion}

Let us reiterate that faith is almost an indispensable ingredient of Nigeria's existence. Faith supports social norms and promotes culture. Adamolekun has noted that Christianity, Islam, and traditional African religions "contain fundamental moral principles on which aspects of our society and culture are built" (2012, p. 5). Conversely, faith has been the agent of bitterness through killings in riots, terrorism, burning of churches and mosques, wanton destruction of lives and property, threat to public peace and the corporate existence of the nation. In all cases, this is normally caused by fundamentalism and religious intolerance. As Adamolekun observes, "fanaticism and fundamentalism in a country like Nigeria where religion is relevant will only lead to chaos, confusion and unrest. Social, political and economic activities of such a society would be seriously affected (p.1). It is in condemnation of extremist faith that the Catholic Church today rejects and regrets all forms of duress employed by her forebears in their fanatic zest to spread the faith in the Medieval era. Modest modern Christianity is guided by the strict examples of tolerance learnt from Christ, the founder of Christianity as He came "to seek out the lost, to save life not to destroy it" (Nwokora, 2014, p. 78).

Fundamentalist versions of Islam have maintained and even advanced some levels of fanaticism, intolerance and the consequent rebellion, violence and anarchy that task national unity and progress. Nwokora laments that while Christians seek to win over atheists, unbelievers and backsliders by preaching, persuasion, prayers, and above all, the example of their own lives, Islam has not got that patience with 'infidels: "Convert or perish seems to summaries(sic) the Islamic code of conduct"(p. 75).

However, Nwokora fails to see that the conversion of "unbelievers" may equally refer to Moslems the way Christians are "infidels." And while fanaticism among Christians may appear as pockets of individual heaves demonstrated in the Eugene 
example and alluded to in the Akaluka episode, we should not gloss over the nagging import of some "born again" Christians' dictum: "Repent or perish," or, "Accept Jesus Christ as your personal lord and saviour or you will never make heaven," or, "Jesus is the only way, the truth, and the life."

Thus, the Christian fanatic has merely eschewed physical violence, routing for psychological warfare, Muslims are daily urged to accept Jesus into their lives, in buses, in market places, sometimes in their homes; often in predominantly Muslim enclaves. And these are people already reified to have little or no tolerance for another's point of view. So, although the "born again" Christians are not violent in the conventional way, these fundamentalist Islamic Jihadists normally claim that the Christian method is a bad way of avoiding conflict (Adamolekun, 2012, p. 3).

Quite objectively, the Islamic fanatic poses the greater danger to national unity in Nigeria. Ibrahim Yaro has explored the danger which Islamic fundamentalism poses to the Nigerian nation and surmises that the concept of violence is in-built in Islam:

In Islam, there are evidences of deliberate preparedness for violence. A case in point is the Izalas which is a militant wing of Moslem students. Of all religions in the world, I have not yet known of any other which devotes part of its wealth and training for active violence (quoted in Nwokora, p. 6).

Both Christianity and Islam struggle to win converts and control the Nigerian space. The way some of their adherents preach, teach and practice betrays intolerance, their false devotion, their make-believe zeal but uncompromising practices are contrary to the fundaments of faith as espoused by the founders.

\section{Faith, the Nigerian Enterprise and the Nigerian Writer}

Rather than evangelism and conversion, faith's greatest achievement and impact in West Africa, particularly Nigeria is its systematic education of the people. It has been observed that "the educated population is a productive population" (Okeke, 2014, pp. 15 -16). This lends weight to John Dewey's insight that "education should seek to develop the characteristic excellence of which humans are capable," since according to Epictetus, "only the educated are free" (1954, p. 112). F. Babalola reveals that the schools acted as agents of conversion because "a number of African children who find their way into (mission) schools...were instructed in the Christian faith and were baptized" (1961, p.25). Aside spreading the Christian faith the products of these schools boosted commerce as, "they became the middlemen between the Africans and European traders"(Babalola, 1983, p. 26).

Tertiary education gave rise to humanistic education. Humanistic education "... contributes immensely to human progress by fostering imagination," and it is "through imagination that man becomes aware of what the universe might be" 
(Okeke, p. 23). Faith entrenched a culture of charity and stamped out barbaric practices like cannibalism, human sacrifice and the killing of twins in Nigeria and some other parts of West Africa. Now, the creativity of the Nigerian writer is often driven by nationalist ideology. Ideology is "a set of beliefs, systematic and delimited mental constructs which orientate the individual or group in term of action" (Ngara, 1990, p. 25).Education acquired through Faith based institutions gave rise to systematic and informed challenge, attack and dismantling of some logo centric portrayal of Africa as exemplified in such works as Edgar Wallace's Sanders of the Rivers, John Buchanan's Prester John, Joyce Cary's The African Witch and Mr. Johnson; and Joseph Conrad's Heart of Darkness.

The activation of cultural values is most pronounced in creative writing and literary engagements in Nigeria. Several scholars find faith complicit in the depletion of Africa through slavery. When the Portuguese Bishop of Sao Tome faced difficulty of funds, notes Babalola, he struck an agreement with his home government and got permission to trade in slaves (1983, p. 127). This kind of action is what led Ojo-Ade to surmise that "the Christian faith is a corpus of contradictions (Ojo-Ade, p. 127). Most problematically, faith fetes Africa, particularly the Nigerian nation with certain disquieting prodigality. This we find in various literary works of African writers like David Diop ("The Vultures"),Chinua Achebe(Arrow of God and Things Fall Apart), Mongo Beti (The Poor Christ of Bomba), Ngugi wa Thiong'o (The River Between and Weep Not, Child), and T. M. Aluko (One Man, One Wife), etc.

This paper will present the extremities of faith that endanger the continued harmony, health and cohesion of the society in the West African sub-region through cross analysis of Chinua Achebe's Things Fall Apart and Chimamanda Ngozi Adichie's Purple Hibiscus (2006) along with a deliberate eclectic interrogation of discernible pitfalls and crudities of faith gleaned from some nonliterary sources whether of the Christian or of the Islamic canvas.

\section{Faithful Prodigals in Fact and Fiction: Engendering Destructive Models}

One of Literature's goals is to enunciate and propagate the cultural values of people. It also mirrors society through realistic and plausible representation. It is germane to our understanding of tolerance. Another of Literature's cardinal goals is the promotion of unity among diverse groups, through advocacy, even if this renders it committed. Chinua Achebe and Chimamanda Ngozi Adichie each capture the problem and danger inherent in religious bigotry and fanatic intolerance manifest in certain versions of particular faiths. Achebe details this danger using the old order, Adichie details the danger using the new.

In Things Fall Apart, Achebe depicts the dilemma, exasperation and tragedy of a gigantic warlord and hero who is fighting to defend an endangered but original 
order - the traditional system - that would progressively be dismissed as archaic through manipulation and strong arm tactics of a stronger faith. In Purple Hibiscus, Adichie represents the tyranny, extremities and ignominious destruction of a wealthy protagonist who practices fanatic and intolerant Christianity.

Each hero (of the old and the new order) dies with ignominy in a fanatical, unthoughtful defence of faith. Both are culprits as well as victims of the globalizing trends in the mastermind religion- Christianity. The one dies attacking Christianity, the other dies over-defending her. Each of them is a static character acting in error, failing to follow the trend of events like Obierika and Akunna in Achebe's and Aunty Ifeoma and the practical, egregious Father Marcel in Adichie's. Each character negates the principle of culture contact and acts on impulse buoyed by arrogant and impractical attempt to ram his faith down every throat that he encounters. In their fanatic zest, both negate the core tenets of their faith: peace and tolerance. While Things Fall Apart betrays a posture of inter-religious conflict, Purple Hibiscus exhibits the trappings of intra religious conflicts.

Both Okonkwo and Eugene fall because they are emotional and fanatical. This is the crux of the problem, the enervating imperatives of national and transnational dilemma and endangerment in the face of inexorable faith that fails to find a wedge, but rather fires on the engine of fanatic resolve like Fela Anikulapo Kuti's "Zombie"as though programmed and hypnotized; with the enchanting magnetism of prodigal faith they cause disharmony, unleash terror and havoc, and precipitate harm not only to the collective but also to them-specific-selves.

In Things Fall Apart, Okonkwo is the fierce force of an ethnocentric culture who pits himself against an emergent but more powerful Christian culture. His fanaticism is characterized by poverty of thought, lack of restraint, and incapacity to weigh the odds, decipher options and consider possible meeting points. He has come from the nadir of poverty to the pinnacle of reckoning as one of the lords of the clan, a custodian of an agrarian culture that sits snug in the old order. Okonkwo's alarm leads him to exasperation and this arguably, is driven by economic and spiritual considerations that call for the sustenance and maintenance of the status quo ante. Like all self-serving zealots, he is aware that not only the belief system is endangered but more alarmingly, the economic system where the king of yams which is ing of kings, is compromised. The problem, as Achebe in a measured authorial intrusion remarks, is that "The white man had indeed brought a lunatic religion, but he had also built a trading store and for the first time palm oil and kernels became things of great price, and much money flowed into umuofiaq" (Achebe, 1958, p. 142).

So, now that hitherto lazy ones may get into wealth and reckoning merely by selling kernels and palm oil, of late domains of women and children, now that king yam has gone to seed and reckons little, the new faith must be confronted with 
fierce force and uncompromising vehemence. The near uselessness of tuberous crops in the white man's trade equation informed the strong opposition to the new dispensation as this often frustrated the 'natives' who regaled in their dexterity in this area of economy (Babalola, 1983, p. 4). This disparate economic interest between the lords of Umuofia and the evangelizing, mercantile Christian faith, probably more than a consideration for the religious, is what got Okonkwo to levels of stifling frenzy in his protection of the status quo.

In Adichie's Purple Hibiscus, Eugene represents the extreme Christian who visits his excesses on whoever fails to 'buy his own,' ranging from Papa Nnukwu, his father to his wife and children, to his younger sister, Aunty Ifeoma down to the Igwe, to those who receive the holy meal wrongly and to just about anyone else who in Eugene's self-righteous estimation, does not measure up to the version of faith of which he fantasizes. Although Eugene's faith guarantees his economic state as it welds well with the global outlook of the Christian faith, yet he is driven by an excessive fear lest his children should fall short of his uncanny pronouncements on what constitutes true faith. And so, like Okonkwo, he ruled his household "with heavy hands."

In fact, Okonkwo and Eugene share a lot of traits respecting their bigoted view of, and disposition to faith. Both are like a dangerous pair of religious rough necks out to do harm where they think that they are striving to do good. Both are rabidly intolerant and suffer from the mastermind syndrome. Being impulsive, flat characters, they hold on to their injurious convictions without qualms.

Okonkwo, for instance, should have borrowed a cunning leaf from Akunna, Obierika or even the White missionary, Mr. Brown. Brown's patient interrogation and subsequent understanding of the Umuofia worldview enables him to apply the restraint and wisdom, that although he has power of force, he has to be careful as "a frontal attack (on the Umuofia tradition, culture and spirituality) would not succeed" (Achebe, 1958, p. 144). Achebe reports that the Umuofia people began to feel that the new faith had something to offer because of Mr. Brown's method; and the man thus earns the people's respect because "he trod softly on faith and made friends with some of the greatest men of the clan" (my emphasis; Achebe, 1958, p. 142).

This is in sharp contrast with Okonkwo's action both during his exile and on the return to Umuofia. While in Mbanta, he had fumed that whoever should defecate on his floor of fanatic faith and agrarian economy should expect a broken head in return, urging his uncles to "not reason like cowards"(Achebe, 1958, p. 127). It is therefore, not surprising that Okonkwo will not be tolerant enough to listen to the other's view like the pragmatic Akunna who entertains and engages Mr. Brown in arguments on each other's idea of the supreme God, sending one of his sons to find out about the new way. Instructive is the fact that although Akunna 
is receptive and open-minded, he is nevertheless firm in his convictions on his faith just as Mr. Brown is of his.

Okonkwo has the opportunity to learn from the Christian faith about the White man and his motives. But, he chases the well meaning missionary out of his compound on the latter's auspicious if naïve visit to Okonkwo threatening that "if he came into his compound again, he would be carried out of it" (Achebe, 1958, p. 145).This is in spite of Obierika's candid warning through a dissection of the situation, against Okonkwo's suggestion of a fight against the new faith, that

It is already too late... Our own men and our boys have joined the rank of

the stranger. They have joined his religion and they help to uphold his government. If we should try to drive out the white man in Umuofia we should find it easy... But what of our own people who are following their way and have been give power?"(Achebe, 1958, p. 141).

Again, Okonkwo is deaf to the warning that the bringer of the new religion is "the most powerful person in the world," and no one was free to mess with her faith and will in her "dominion" (Achebe, 1958, pp. 154 - 5). Okonkwo is not merely informed. He has seen and tasted this power so that this subtle threat should ticket home but he blindly regales in the past of his glory when power configurations were locally determined.

When one fanaticism and religious bigotry meets headlong with another, the stronger god often represented by the group with the greater capacity for violence, often prevails. This is how Okonkwo's fanaticism measures with Mr. Smith, the White missionary's fanatic intolerance and results in desecration through the unmasking of an Umuofia ancestral spirit, precipitating the burning of zealot Smith's church, the consequent detention and humiliation of the lords of Umuofia by the administrative and political arm of the stronger Christian faith, culminating in Okonkwo's impulsive killing of the white administrator's cheeky messenger, leading to Okonkwo's eventual self destruction borne of frustration and disappointment.

Smith's unmasking of the Umuofia ancestral spirit and Okonkwo's subsequent beheading of the white man's messenger are both reminiscent of the cruel beheading of the Christian zealot, Gideon Akaluka in Kano State, Nigeria by some abrasive Islamic fanatics, 1994, on the excuse that the victim desecrated an Islamic leaflet. This has continued to cause acrimony between the Southern (Igbo) guests whose kinsman was murdered with his head missing till date, and their northern (Hausa/Fulani) landlords whose almajiri are ever ready tinder for igniting the fanatic fire of the Islamic religion (Adamolekun, 2012, p.3).

Okonkwo's tragedy does not lie in his killing of the white man's messenger who rudely taunted and ordered him out of the way. His tragedy lies in the fact that at that telescopic moment of sober catharsis, "he discerned fright " in the people's 
tumults, for the first time it dawns on him that he has taken his zealotry a scale too high. Rather than gain approbation, Okonkwo receives condemnation. People in apparent disapproval of his action and trepidation for consequences blame Okonkwo with "Why did he do it"(Achebe, 1958, p. 163). So, things actually fall apart because the foremost lord and protagonist of Umuofia could not wait soberly and cautiously to apprehend the poetics of the new faith in all its dynamics.

True, Okonkwo had led the clan in warand he had been an emissary of war or peace, successfully. But then, all Umuofia had given him commission. In this case, he could not gain, or wait to see if he could gain solidarity in this matter of faith to support a process that discriminates against, and ostracizes some of its ardent adherents. Faith is personal and works the best where it touches the individual core as well as the common essence.

In Adichie's Purple Hibiscus, rather than starting to fall apart, things begin to come to a head when Chukwuka - God is supreme -, alias Jaja confronts and defies his father, Eugene's bigoted and tyrannical treatment of his family on the faulty premise of fastidious faith. Witness the self-righteous violence, mayhem and threat to national cohesion posed by the 'godly' aspiration of blood, of the Maitatsine fanatics in Kano (1980), the terrorism of the Shiite Moslems (1996 -19997 and since 2016 till today) ,and the current raging 'judgement in blood' and criminality of the rampaging Islamic sect, Boko Haram in Nigeria which has spread to Cameroun, Niger and Chad, respectively.

Jaja fails wittingly "to go to communion," with the excuse that "the wafer (host in catholic parlance) give bad breath" (Adichie, 2006, pp.11, 14).To call the 'host' wafers in a Catholic home is apostate, impudent and deplorable all right; but Jaja seems to indulge in this impudence not as a disavowal of faith, nor to denigrate or challenge God. It is probably to spite, to confront and to call his father's bluff on the latter's righteous excesses and intolerance. Eugene insists that all must live by the book as spelt out by him and the archaic and dogmatic Father Benedict. He did not reckon that some of the faithful, like Jaja and Kambili might be better attuned to the dynamism of Father Amadi and Aunty Ifeoma whose fluid and pliable but firm and humane Catholicism is more reasonable, more democratic and more enlightening to the young progressive minds and even to most other faithful.

Eugene's total domination and tyrannical stranglehold on everyone is a kind of power that calls to power. It is an unwitting but stifling violence that calls to the balancing of terror. It is the biggest form of violence in Eugene's estimation for anyone not to attend the holy mass for two consecutive Sundays; which is why after receiving the holy communion,

He sat back and watched the congregation walk to the altar and after Mass, reported to Father Benedict with concern, when a person missed communion for two successive Sundays... Nothing but mortal sin would 
keep a person away from communion two Sundays in a row (Adichie, 2006, p. 14).

Such is Eugene's fanaticism and intolerance that he orders his children, on pain of torture to spend only five minutes with Papa Nnukwu, his father during the once-in-a-year visit that the children are allowed to pay the old man. What is more, the children may not sit down, drink water let alone eat anything from the old man's hand "because he is a heathen."Such is Eugene's blind faith and hatred of his father that even when the old sage was on the point of death, Eugene is only worried that his children should share a roof with a heathen in Aunty Ifeoma's University apartment in Nsukka. So, he "went on and on about a heathen being in the same house as his children"(Adichie, 2006, p. 88).

Thus, for sleeping in the same house with a heathen without alerting their father, Eugene scalds his daughter Kambili's feet with steaming hot water, solemnizing the orgy with, "You should strive for perfection. You should not see sin and walk right into it."Kambili reports: " he poured the hot water on my feet, slowly as if he was conducting an experiment and wanted to see what would happen...The pain of the contact was so pure, so scalding (Adichie, p. 2006, 201).

To prove that he was completely possessed by the demon of fanaticism and an inconsiderate enforcement of a distorted version of faith, Adichie reports, "he was crying, tears streaming down his cheek," as he administered purgatory and torture of the innocent, helpless girl (Adichie, 2006, p. 201). It appears that while exacting the punishment on Kambili, Eugene is feeling rapturous at the prospect of dinning and winning with Christ thereafter or in the nearest future.

In this particular, as in his gnarling of Jaja's finger for a small offence, or on wife battery which causes Beatrice's miscarriage, or on his refusal to help cater for his father, or on tying acts of charity and familial obligation like buying a car for Aunty Ifeoma to the condition that her children join a league in the church, or on his refusal to honour the Igwe, presumably because the latter's faith is not deep enough; in all these and more, Eugene descends as low as the Islamic Maitatsine fanatics of the 1970s and early 1980s which most probably gave rise to the current decapitating and ruinous regional headache, the Boko Haram Islamic sect.

Thousands of the Maitatsines had blissfully embraced their death in the hands of the Nigerian State operatives. Their blind bliss, much like Eugene's, inheres in the urgent need to die and enter the gates of heaven before their leader, Mohammed Marwa should die and close the heavenly gate against late comers, as the charlatan had boastfully brainwashed the gullible followers. Only the killing of Mohammed Marwa and the public display of his corpse would eventually convince those faith geniuses that the gate of heaven was closed and any subsequent deaths would be in vain (Soyinka, 2000, p. 73; Adamolekun, 2012, p. 3). This is akin to the Guyana tragedy of group suicide orchestrated by the Reverend Jimmy Jones where 
900 adherents died from cyanide poisoning and gun shot wounds (Deon Price, 2018, p. 2).Eugene's brand, or at least manner of execution of faith is in a sense, of akin to the Maitatsine's. It is step-brother to the Boko Haram fanatic criminality and lends a conspiratorial finger to the ongoing but ebbing dehumanizing activities of the ISIL or ISIS (Islamic State) in Syria and Iraq. What is more, Eugene's denigrating attitude to the Igwe and Papa Nnukwu is in a sense, akin to the fundamentalist posture of the Yantatshine - the Maitatsine warriors, and the Mallam Ibrahim El Zak Zaky founded Shiites' seeming intolerance of the moderate Sunni Muslims (El Rufai, 2019, Interviews).

Eugene works his fanaticism to the point where his hitherto pliant family could no longer absorb his excesses. What follows is defiance and occasion soon gives for its demonstration. Kambili has cherished her grandfather and has kept as relics, a painting of the grand old man made at Nsukka by kambili's cousin, Amaka to remind them of the dead patriarch. Eugene spies out this painting, considers it apostate, tries to wrest it off Kambili to destroy. This is too much for the poor girl who clings to the painting, Eugene goes berserk:

'Get up,' Papa said again. I still did not move. He started kicking me. The metal buckles on his slippers stung like bites from giant mosquitoes. He talked non-stop, out of control, in a mix of Igbo and English... 'Godlessness. Heathen worship. Hell fire.' The kicking increased in tempo... I curled around myself tighter, around the pieces of the painting, they were soft, feathery. They still had the metallic smell of Amaka's paint pallet. The stinging was raw now, even more like bites, because the metal landed on open skin on my side, my back, my legs... A salty wetness warmed my mouth. I closed my eyes and slipped away into quiet (Adichie, 2006, pp. 216 -7).

Beatrice, mother of the tortured girl is helpless and suffers in spite of herself and her children. True, they live in opulence. They are wealthy and want nothing material. But, what they want is bigger than silver and gold. They lack freedom, free conscience, freedom of association and free speech. They are in need of happiness. They are tethered by their fanatic husband and father. Eugene is wealthy, almost kind but mortally deformed by his misconception of essential catholic Christianity.

As power calls to power, so does tyranny call to violence. Jaja becomes resolute with a different kind of fanaticism: to end the suffering for himself, his mother and his younger sister, Kambili. Kill the fanatic. Kill this enemy of faith, of humanity, and of free conscience, Jaja decides and thus poisons his father. This action is a subliminal crusade, a clarion call to rise up and defend humanity against the prodigals of faith. It is more awesome than the call of Pope Urban to the nobles of Claremont. Since "the peace" and "the truce" of God could not avail, then face frontally, the enemy (ies) of the way. To him, Kambili's suffering is the last straw. 
Although, Jaja's patricide is taboo in the Igbo setting of the novel, it nevertheless shows that fanaticism is a hindrance to the cause of propriety and faith. Perhaps, Beatrice would have committed this crime if Jaja had not. She sublimates this subconscious impulse by initially acquiescing to the guilt charge. In any case, Jaja was the first to revolt, followed by Kambili.

Jaja's action is similar to the Christians' retaliatory action in Kano, 1991 against their Moslem fanatics' assailants in what came to be called "The Reinhard Bonke Riots" where churches and mosques alike were torched, with thousands of lives lost, a demonstration that no one has a monopoly to violence (Adamolekun, 2012, p. 3). Sadly, in such situations, both national and regional peace and unity is dangerously threatened.

Eugene, almost more than his incarnate, Okonkwo is a faithful prodigal, a wastrel of the sanctity and chastity of faith, a spendthrift of the promises of Christ. $\mathrm{He}$ is a destroyer of the Christian precepts of tolerance, peace and goodneighbourliness: he forces Jaja to hate him and to sublimate his Oedipal tantrums to levels of patricide. Eugene is an anti Christian hero who forges the iron cuffs of impossible versions of faith to fetter and curtail the spread of the good seed.

True, Eugene performs religiously, all his obligations and acts of charity to the church. He pays much more tithes than anyone else and provides the wafers for the host. He donates generously for the uplift of the church and on occasions, feeds various church leaguse. Above all, he makes no noise about his philanthropy with the church. But then, Christ's salvation is for both the 'Jews and the gentiles.'

To this extent, Eugene typifies the character of whom Frank Edwards details in "Is Your Name in the Book of Life:" a man dies and finds himself at the gate of heaven but has to locate his name in the book of life to qualify to enter heaven. Agitated but confident, the man reels off:

Mr. Angel I am a stranger I don't know what's going on here...I am (sic)a pillar in my local church, I gave the offerings and paid my tithes, fed the poor and had myself a good name. So, is my name in this book of life? Is my name in this book of life? Is my name in this book of life yea...aah (Edwards,2010, track 5).

Of course, the man's name was not in that Book because "only the pure at heart" will see Jesus" (Edwards, 5).

Aunty Ifeoma is a foil to her brother, Eugene. A university teacher and widow, she displays uncommon courage to tell the truth. No less devoted to God than Eugene, she is open-minded, tolerant and has a pure heart. She it is who fends for and takes proper care of her old father with her relatively paltry earnings. Relative to Eugene, she is poor but love, happiness and guided freedom are the lots of her children. Singing and laughter reigns in her home. For instance, Amaka is free to 
watch television, wear her make-up at age 15, bring some of her friends home where they "talk about a Math teacher who did not know the answer to his own test," and "a girl who wore a miniskirt to evening lesson though she had fat yams on her legs, and a boy who was fine" (Adichie, 2006, p. 149).

It is this freedom by their cousins that exposes Jaja and Kambili to the fact that life can actually be less mechanical, less regimental, livelier and freer. This is what makes Jaja to challenge his father by refusing to wait for the Holy Communion, and leaving the table, when challenged. Kambili on her part freezes with wonder at Amaka's precocious pertinacity, at Aunty Ifeoma's audacity to call Papa 'Eugene,' to his face, of Father Amadi's marked difference from Father Benedict - Amadi allows for song in Igbo to punctuate the rosary, Benedict wants song strictly in Latin except, ironically, during offertory. Jaja and Kambili also find that grace could be said for less than thirty minutes and the lord of hosts will still accept and not punish anyone.

Eugene treats Beatrice like a primordial slave, beating her at will and causing her to miscarry twice. He loathes Papa Nnukwu because the old man could not follow the Christian faith. On this score, Eugene excommunicates his father and refuses to build him a befitting house; and in spite of his tremendous wealth, he abandons the old man to die almost destitute. This is why Papa Nnukwwu advises Father Amadi never to lie to his grandchildren and never to "teach them to disregard their fathers" (Adichie, 2006, p. 179), a time-honoured item of the "Ten Commandments' of the Bible and of the Christian faith which Eugene flouts in his fanatic frenzy.

Now, on Okonkwo's part in Things Fall Apart, we could say that by dying through un-thoughtful actions guided by wooly headed fanaticism and blind defence of primordial interests, he sets the stage for the quick erosion and swift emasculation of the ethnocentric culture that he struggled to protect. Okonkwo, like most other defenders of faith fails to let Baal fight its war. He must do Baal's battles for Baal. This is the crux of the bane of faith, that men deem it their provenance to fight for the 'Almighty' powers as though their 'gods' were a helpless old weakling needing human protection.

\section{Conclusion}

It has been shown that without faith, human development may have been retarded. We established that faith has been of tremendous importance to the development of the world, Africa and the Nigerian nation. We scored the point that faith is a cardinal factor of our national life. It is noted that there are brands of faith which are inimical to the corporate cohesion and existence of not just Nigeria and Africa but the entire globe. Some religious charlatans and sometimes, the faithful, because of wooliness sometimes fail to grasp the language of tolerance. This is 
bigoted faith which results in perennial religious heaves like the wanton destruction of lives and property and the ensuing endangerment of the total polity. This brand of faith is paraded in the main by Islamic fundamentalist; and this has been taking the centre stage of national concern since the early 1980s to the present.

The study contends that violence carried out against humanity in the guise of protecting or projecting the image of God is ridiculous and counter-productive since it is self-serving and hypocritical. It is at best, the handiwork of rough necks bent on making economic and political capital out of faith.

On the other hand, Christianity thrives on psychological violence which if vexatious, does not directly constitute danger to the nation except to the level that its preaching excites violence on the unbeliever, particularly the Muslim fanatic. But being that its essential method is psychological, this paper considers Fanatic Christianity dangerous based on the potential to ignite violence from bigots of especially the Islamic order. The study insists that moderation and tolerance are the best approach to curtail or even checkmate the high incidence of religious confrontation not just in Nigeria but the entire West African sub-region. Again, preaching that lays claim to exclusive right to the key of heaven promising wholesale damnation to non adherents is dangerous and patently unhealthy for the secular imperatives of the Nigerian nation and world peace. In a similar vein, any culture that pretends to superiority and plans to subsume others within its ambience is toeing the path of disaster. Nigeria is multicultural and her collective best bet to retain political indivisibility, economic growth and world respect is for all sections of the polity to recognize that verity.

True, all religions thrive on the promises of reward or punishment of the faithful and the profligate, respectively. Care must be taken to ensure that in doing the work of God, we may not be seen to be serving Mammon. This is what we demonstrated in the two creative works that engage our discursive adumbration. We analysed Okonkwo's and Eugene's levels of bigotry in an eclectic recourse to factual action of the Islamic hue, and found that fanaticism is often an item of intolerance which leads to responses which negate the essential qualities of quintessential faith such as peaceful coexistence, good neighbourliness, acts of charity and a patriotic consideration for the preservation of national ethos.

Finally, the study affirms that faith built on the hatred of those who hold a different view with regard to religion is inimical to the peace of God. Faith urged on skeins of mechanical outlook, that is tyrannical and inconsiderate must be denounced and discountenanced. The kind of defence put up by Okonkwo for his ethnocentric culture which blinds him to the prospect of dialogue with representatives of the emergent religion, that makes him kill and get killed, is a 
danger to essential faith and hinders rather than help the cause of faith and national constructive engagement.

The kind of faith which Eugene exhibits, where he forces a regimental life on his wife and children, that makes him to disown his father and deny him succour in his old age, that makes him scald Kambili's feet, gnarl Jaja's finger, beat his wife until she miscarries, beat Kambili into fainting fits, force his cherished ones to hate and kill him - such faith is steeped in prodigality. Such is the provenance of faithful prodigals. It is sure to render the political, economic and religious life of a given polity precarious.

Lastly, this paper posits that religious fanaticism has to be faced frontally and contained. The study therefore, insists on systematic, conscious reorientation and reification strategies that target the young of kindergarten age who are not yet tainted. One sure way to achieve fruitful result in this regard is the use of creative works deliberatively toned toward nationalism, patriotism and religious tolerance.

\section{References}

Achebe, C. (1958).Things Fall Apart. London: Heinemann

Achebe, C. (1983). The Trouble with Nigeria. Enugu: Fourth Dimension

Adichie, C. N. (2006). Purple Hibiscus. Lagos: Farafina

Babalola, F. A. (1983). Christianity in West Africa. Ado-Ekiti: Bamgboye and co

Bainton, R. (1952). The Church of our Fathers. Philadelphia: The West Minster Press.

Adamolekun, T. "Religious fanaticism in Nigeria since 1980: a historical perspective." in British journal of arts and social sciences 9:11 (2012), pp. 78 10 (http // www.bjournal.co.uk/BJASSaspx) Retrieved june12, 2018.

Edwards, F. (2010). Unlimited. Gospel Song, track 5. Abuja: Sen Sounds.

Epictetus (1954). Enchiridion. London: West Minster Press.

Goldberg, N. (2005). Writing down the bone, freeing the writer within. Boston: Shamghbala.

Monrose, T. G. (2010). "The role and importance of the church in contemporary development." Retrieved

www.huffingtonpost.com/pastorgilfo.retrieved September19.2019

Igwe, D. (2014). "How to achieve economic and cultural renaissance of the Igbere people." Saturday Sun. October11, pp.32 -33

Ngara, E. (1990). Ideology in African Literature. Nairobi: University of Nairobi Press.

Nwokora, L. N. (2017). Culture, literature and nationalism. Enugu: Snaap Press. Ojo-Ade, F. (2011). "The Black man's burden: Christianity in black African Fiction.” in Centre for blacks and African culture and civilization (CBAAF). 
Okeke, V. (2015). Pastoral Letters. Enugu: FOP Publishers.

Onukogu, A. A. \& Onyerionwu, E. (2009). 21 ${ }^{\text {st }}$ century Nigerian literature. Ibadan: Bookcraft.

Osundare, N. (2008). Literary communication in African fiction in English. Ibadan: Hope Communications.

Price, D. (2018). "This Youth Generation of Guyana Tragedy Still Haunting after 40 years." Retrieved from: www.guyanatragedy.his.com/revjones. viewed October,2018. Viewed July 12, 2019.

Reade's Digest Library of Modern Knowledge2 (1978). London: The Readers Association.

Serlomy (1985). The narrow path. Ibadan: Heinemann

Soyinka, W. (2008). Interventions of Power. Ibadan: Bookcraft

Theatrice, W. \& Kallama, B (2003)."The role of the church in contemporary development." Retrieved from: www.juraumn.edu/...69201. Viewed August, 2018.

Udumukwu, 0. (2014). The Development of Nigerian Literature. Unpublished papers. Port-Harcourt, University of Port-Harcourt.

Vatican Council II. More Post Councillar documents. Harry, J.C. \&Austin, F. eds, Weber, M. (1958). Capitalism and the protestant ethic. New York: Scribner (https:www.worldcat.org/title/protestant-ethic-and-the-spirit-ofcapitalism/.../391919).retrieved June18,2019.

The Holy Bible. King James version. www.bible.cald.7promisess-god-hyml. Retrieved July 192019 www.Islamweb.net/g-mainpage/articled. Viewed October 18, 2018

\section{Contact}

\section{Ogbu Chukwuka Nwachukwu, PhD.}

Department of English and Literary Studies

Alex- Ekwueme Federal University,

Ndufu- Alike, Ikwo, Nigeria

E-mail: chukwukanwachukwu158@gmail.com 